\title{
GENETIC DIVERGENCE AMONG Passiflora cristalina Vanderpl \& Zappi. GENOTYPES BASED ON FLOWER AND FRUIT CHARACTERISTICS ${ }^{1}$
}

\author{
GREICIELE FARIAS DA SILVEIRA ${ }^{2,}$ ANA APARECIDA BANDINI ROSSI ${ }^{3}$, \\ TATIANE LEMOS VARELLA ${ }^{4}$, MAURECILNE LEMES DA SILVA CARVALHO 5 , \\ CAROLINA JOANA DA SILVA ${ }^{6}$
}

\begin{abstract}
This study aimed to evaluate the genetic divergence among Passiflora cristalina genotypes and quantify the relative contribution of 30 flower and fruit characteristics, seeking to support the preservation and characterization of genetic resources of the species for preservation and use in future breeding programs. We evaluated 150 fruit and 150 flowers collected in 15 genotypes with naturally occurring in the municipality of Alta Floresta, MT. The characterization of genotypes was performed through 30 morphological characteristics of flowers and fruits, 21 of these for flower and 9 for fruit. Data were evaluated using the principal components and cluster methods obtained by UPGMA method from the similarity matrix (Euclidian mean distance), using the Genes software. By principal component analysis, it has been found that the first three components have absorbed $52.11 \%$ of the accumulated variation. The characteristics that most contributed to the discrimination of genotypes were fresh fruit weight, stigma length, length of corona filaments, fruit width, petal width and pulp weight, which are more responsive for the selection of P.cristalina genotypes. Smaller contributions to diversity were obtained from anther width, bract width and fruit length. The smallest contributions for diversity were obtained from the following characteristics: anther width, bract width and fruit length. Through UPGMA clustering method, it was found that there is a large genetic divergence among genotypes analyzed because all genotypes were grouped with over $50 \%$ of dissimilarity. This study identified genotypes 4,5 and 9 as the most divergent and therefore the most suitable for breeding in future breeding programs and genetic conservation of the species.
\end{abstract}

Index terms: Passion fruit, Morphological descriptors, Plant resource.

\section{DIVERGÊNCIA GENÉTICA ENTRE GENÓTIPOS de Passiflora cristalina Vanderpl \& Zappi. BASEADA EM CARACTERES DE FLORES E FRUTOS}

\begin{abstract}
RESUMO - O presente trabalho teve como objetivo avaliar a divergência genética entre genótipos de Passiflora cristalina e quantificar a contribuição relativa de 30 caracteres de flores e frutos, auxiliando o resgate e a caracterização, visando à preservação e o uso em futuros programas de melhoramento. Foram avaliados 150 frutos e 150 flores coletados em 15 genótipos com ocorrência natural, no município de Alta Floresta, MT. A caracterização dos genótipos foi realizada mediante 30 caracteres morfológicos de flores e frutos, sendo 21 destes para flor e 9 para fruto. Os dados foram avaliados utilizando as metodologias dos componentes principais e do agrupamento obtido pelo método UPGMA, a partir da matriz de dissimilaridade (distância euclidiana média), com auxílio do programa Genes. Pela análise dos componentes principais, verificou-se que os três primeiros componentes explicam 52,11\% da variação acumulada. As características que mais contribuíram para discriminação dos genótipos foram peso fresco do fruto, comprimento do estigma, comprimento dos filamentos da corona, largura do fruto, largura da pétala e peso da polpa, sendo estes caracteres mais responsivos para seleção dos genótipos de $P$. cristalina. As menores contribuições para a diversidade foram obtidas dos caracteres largura da antera, largura da bráctea e comprimento do fruto. Por meio do método de agrupamento UPGMA, foi possível constatar que uma grande divergência genética entre os genótipos analisados, uma vez que todos os genótipos se agruparam acima de $50 \%$ de dissimilaridade. Com esse estudo, foi possível identificar os genótipos 4; 5 e 9 como os mais divergentes e, consequentemente, os mais indicados para cruzamentos em futuros programas de melhoramento e de conservação genética da espécie.
\end{abstract}

Termos para indexação: Maracujá, Descritores morfológicos, Recursos vegetais.

\footnotetext{
1(Paper 136-15). Received: May 18, 2015. Accepted: April 12,2016.

${ }^{2}$ Biologist. M.Sc., Plant genetics and breeding, UNEMAT. Alta Floresta - MT.CEP: 78580-000. Email: greicielefarias@hotmail.com ${ }^{3}$ D.Sc., Genetics and breeding. Professor at the Faculty of Biological and Agrarian Sciences. UNEMAT. Alta Floresta - MT. Laboratory of Plant Genetics and Molecular Biology. CEP: 78580-000. Email: anabanrossi@unemat.br

${ }^{4}$ Biologist. M.Sc., Plant genetics and breeding, UNEMAT. Alta Floresta - MT.CEP: 78580-000. Email: tatvarella@gmail.com

${ }_{5}^{5}$ D.Sc., Genetics and breeding. Professor at the Faculty of Biological and Agrarian Sciences. UNEMAT. Tangará da Serra - MT. In vitro morphogenesis and plant biotechnology. CEP: 78300-000. Email: maurecilne@gmail.com

${ }^{6}$ D.Sc., Ecology and Natural Resources. Center for Research on Limnology, Biodiversity and Ethnobiology of Pantanal. Bionorte Network / MT. UNEMAT. Cáceres - MT. CEP: 78000-000. Email: ecopanta@terra.com.br
} 


\section{INTRODUCTION}

Brazil is considered a center of diversity of the genus Passiflora (MANICA, 1981) due to its wide intra- and inter-specific genetic variability (BELLON et al., 2009). Some wild passion fruit species present characteristics of interest for passion fruit cultivation, such as longevity, adaptation to adverse climatic conditions, increased flowering period, higher concentration of chemical components of interest for the pharmaceutical and cosmetic industry, and the possible presence of genes for resistance to diseases (Junqueira et al., 2006).

The genus Passiflora also has great importance in the agricultural sector due to its high productivity, acceptance in the world market and diversified use in the cosmetics industry. It is also used for medicinal, ornamental, and food purposes, being consumed as fresh or industrialized fruit, such as juices, ice cream, sweets, liqueurs and jellies (MELETTI, 2011).

The changes caused by the anthropic action have promoted the genetic erosion of the genus Passiflora as a consequence of the expansion of the agricultural frontier mainly in mid-northern Brazil (FERREIRA, 2005). Genetic erosion may result in a narrowing of the population genetic base and loss of important genes, which may lead to a reduction in the ability of species to respond to environmental adversities (RAPOSO et al., 2007). Thus, rescue, description and evaluation of these species are necessary.

In this context, studies on the genetic diversity among genotypes are of great importance because they will provide information about available genetic resources and subsidies for their characterization. Among the procedures used to evaluate genotypes, multivariate methods in which several characters can be simultaneously evaluated have offered effective contributions in the identification of individuals to be used in breeding programs and also in the indication of features that best contribute to genetic divergence (MOHAMMADI; PRASANNA, 2003; CRUZ; CARNEIRO, 2006).

The aim of this work was to evaluate the genetic divergence among Passiflora cristalina Vanderpl \& Zappi genotypes and to quantify the relative contribution of 30 flower and fruit characteristics, in order to help rescue and characterize the species' genetic resources.

\section{MATERIAL AND METHODS}

To estimate the genetic divergence, 15 genotypes were sampled in different forest fragments in the municipality of Alta floresta (Figure 1). From each genotype sampled, 10 fully expanded flowers (Figure 2A) and 10 mature fruits (Figure 2B and 2C) were collected, totaling 150 fruits and 150 flowers.

The characterization of genotypes was performed using thirty (30) morphological characteristics of flowers and fruits, some of them related by the National Service of Cultivar Protection (SNPC), linked to the Ministry of Agriculture, Livestock and Supply (MAPA, 2008) and others proposed in this study.

Twenty one (21) descriptors were used in flower evaluation, namely: flower length (CFF), from the androginophore up to the end of the floral peduncle; flower diameter (DFF) from the end points of petals; androgynophore length (CAF), the full extent that supports the sexual organs; petal length (CPF), from the insertion in the flower to the apex; Width of the petal (LPF), in the largest dimension; Length of the sepal (CSF), from the insertion in the flower to the apex; petal width (LSF) in the largest dimension; anther length (CAF); anther width (LAF); fillet length (CFI); stigma length (CEF); stigma width (LEF); stylet length (CSF); ovary length (COF) and ovary width (LOF); bract length (CBF); bract width (LBF); corona diameter (DCF), from the end points of the corona filaments; size of external corona filaments (FCO); size of the floral tube (TFF), from the insertion into the flower receptacle; size of the floral peduncle (TPF), from the flower receptacle until its insertion in the stem. All quantitative characteristics were measured in millimeters with a digital caliper with precision of $0.01 \mathrm{~mm}$.

Fruits were evaluated through nine characteristics, and fruit length (CFU), fruit width (LFU), fruit thickness (EFF) and peel thickness (ECF) were performed with the aid of digital caliper with accuracy of $0.01 \mathrm{~mm}$. Using a precision scale of $0.00001 \mathrm{~g}$, fruit weight (PFF) was obtained.

To obtain pulp weight (PPF), fruits were sectioned, pulp with the seeds were placed in a Petri dish and weighed together. Soon after, seeds were isolated from the pulp with the aid of a sieve, by means of manual friction and then weighed. Seed weight was subtracted from the pulp + seed weight and thus the pulp weight was obtained. Subsequently, the number of seeds per fruit was evaluated.

Soluble solids content (BRIX) was evaluated by direct reading in manual refractometer with the 
data corrected for temperature.

Multivariate analyses were performed to obtain genetic divergence estimates of genotypes using the Standard Euclidean Mean Method. Based on the distance matrix generated, individuals were grouped by the UPGMA method (Unweighted Pair Grouped Method Average), based on visual analysis, the cutoff point was established at the place of occurrence of the abrupt change in branches present in the dendrogram ( $90 \%$ dissimilarity) and principal component analysis. Statistical analyses were performed using the GENES software (CRUZ, 2008).

\section{RESULTS AND DISCUSSION}

By analyzing the main components, it was verified that the first three components absorbed $52.11 \%$ of the total variation, with the first component explaining $22.45 \%$ and the second component explaining $39.27 \%$ of the total variation, Table 1 .

The accumulated variation was distributed among several components, not retaining the maximum variation in the initial components, as indicated by Cruz et al. (2004) and Cruz and Carneiro (2003), but similar to what has been observed in studies carried out by Godoy et al. (2007), who studied the genetic diversity among passion fruit genotypes and found $69.07 \%$ of the total variation in the first three main components. In hybrid progenies obtained from the P. gardneri $\mathrm{x}$ P. gibertii crossing, Belo (2010) observed $72.20 \%$ of the variation in the first three components, and the first main component explained $47.70 \%$ of the total variance. Crochemore et al. (2003) studied the genetic diversity in passion fruit species and showed that the first and second components explained $29.60 \%$ and $19.40 \%$ of the total variation, respectively, while the third only $12.20 \%$.

For the first component, variables that most contributed to the discrimination of genotypes were PFF (0.32) and CEF (0.29). In the second component, FCO (0.32) and LFU (0.16) stood out, and for the third component, the characteristics that presented a higher value were LPF (0.36) and PPF (0.18). These variables are those that most contributed to estimate the genetic variability of the species and, therefore, are more responsive to the selection of $P$. cristalina genotypes in future breeding programs.

The descriptors of lower contribution to the genetic divergence of $P$. cristalina genotypes were LAF, LBF and CFU, later discarded, according to criteria suggested by Cruz and Regazzi (1997). Thus, when the last principal components are evaluated, the characters that little contributed to the total variation will be the most passive of discards.

Cruz et al. (2004) emphasize that dispensable features are invariant or redundant because they are correlated with others. The reduction in the number of features by eliminating those that little contribute to the description of accesses in the genetic breeding programs makes the evaluation process less costly (ARRIEL et al., 2004), saving time and material resources, at the same time that provides information for the conservation of the species under study (ALVES et al., 2003).

Using the UPGMA grouping method with a $90 \%$ dissimilarity cut line, it was possible to observe the formation of four distinct groups due to the genetic divergence in relation to the features evaluated (Figure 3). Genotypes 1;3;2 and 9 composed group I, the 2 genotypes $12 ; 15 ; 14$; $7 ; 8 ; 6$ and 11 group II, genotype 5 group III and genotypes $10 ; 13$ and 4 group IV, suggesting that genotypes in the same group have a higher degree of genetic similarity. Isolated genotypes, that is, those that formed a separate group, such as genotypes of group I ( $4 ; 13$ and 10) have greater genetic divergence in relation to the others, with genotype 4 being the most dissimilar. In this way, these genotypes present promising features, which may increase the efficiency in future breeding and genetic conservation programs of $P$. cristalina.

Group I formed 3 subgroups, with IA consisting of genotype 1 and 3; IB of genotypes 2 and IC of genotype 9. In group II, the formation of five subgroups was observed, with IIA composed of genotype 12 and 15, IIB of genotype 14, IIC of genotypes 7 and 8, IID of genotype 6 and IIE of genotype 11, while in group IV, the formation of two subgroups occurred, with IVA with genotypes 10 and 13 and IV B with genotype 4.

In the dendrogram obtained, the 15 genotypes sampled are divergent since all genotypes have grouped above $50 \%$, which may be correlated with the large variation of the phenotypic features, probably associated with the genetic variability existing in $P$. cristalina This grouping percentage may be due to the autocompatibility system of plants, especially crossing non-domesticated species, as is the case of the species under study. According to Cunha et al. (2004) and CRUZ and CARNEIRO (2006), these characteristics favor the selection in breeding programs and the conservation of many species, since they allow to describe and differentiate accesses and identify contrasting genotypes in order to perform promising crosses. 


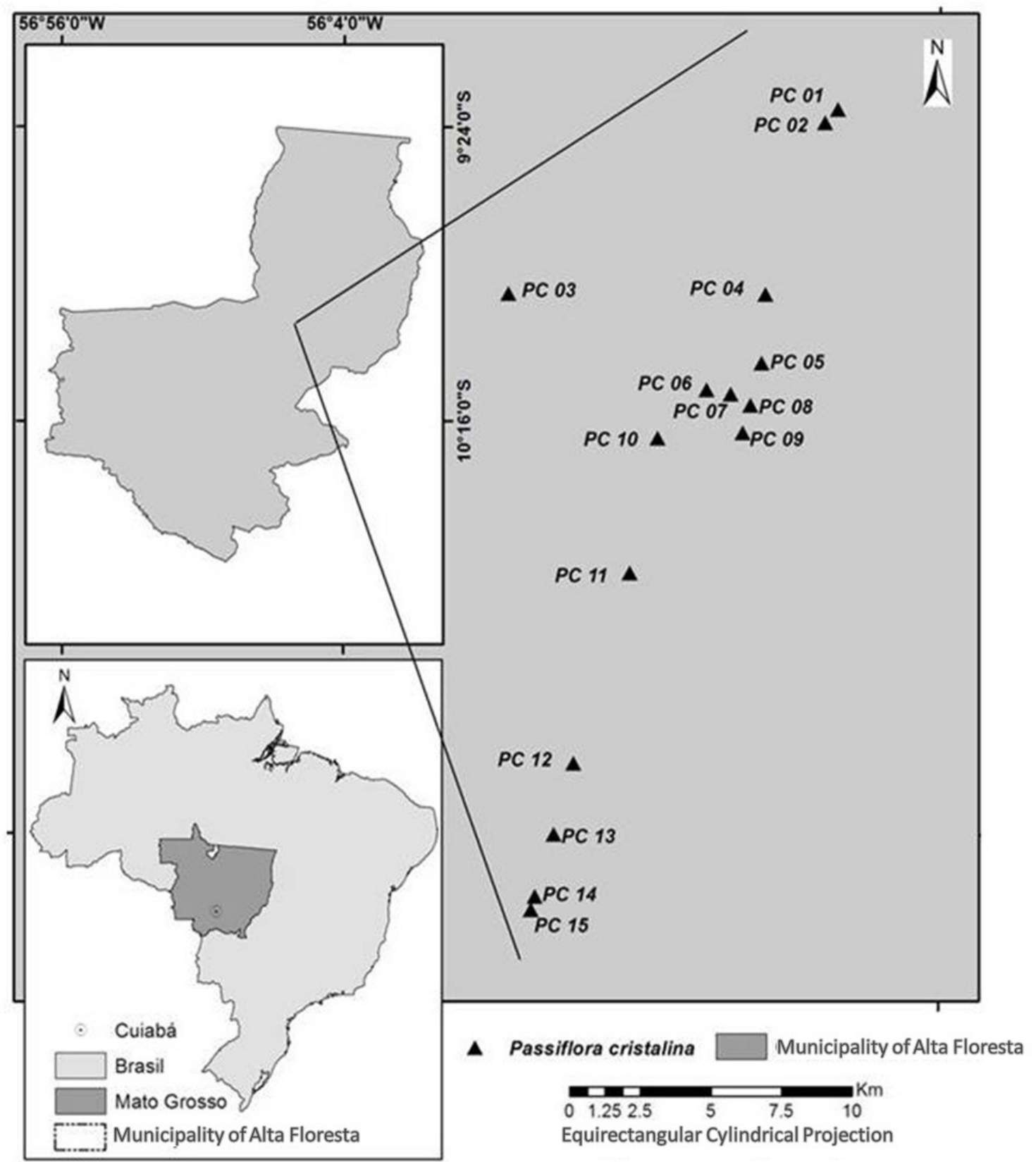

FIGURE 1 - Location and distribution of Passiflora cristalina Vanderpl \& Zappi individuals in the Municipality of Alta Floresta, Mato Grosso, 2013. 

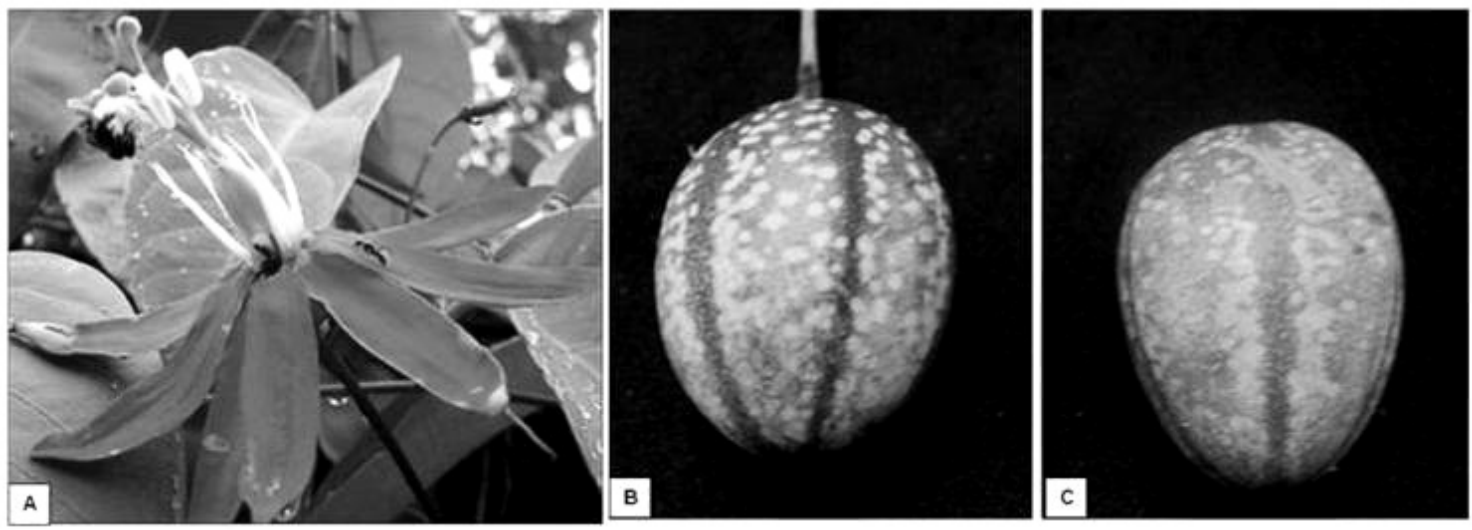

FIGURE 2 - A) Passiflora cristalina Vanderpl \& Zappi flower; P. cristalina Fruits B) Green fruit; C) Ripe fruit. Alta Floresta - MT, 2013.

TABLE 1 - Estimates of eigen values associated to the principal components (PC), eigenvalue (EV), relative importance (RI) and accumulated relative importance (ARI), referring to 30 morphological descriptors of Passiflora cristalina Vanderpl \& Zappi. Alta Floresta - MT, 2013.

\begin{tabular}{cccc}
\hline PC & EV & RI $(\%)$ & ARI \\
\hline 1 & 6.73 & 22.45 & 22.45 \\
2 & 5.04 & 16.81 & 39.27 \\
3 & 3.85 & 12.84 & 52.11 \\
4 & 2.91 & 9.71 & 61.83 \\
5 & 2.57 & 8.58 & 70.41 \\
6 & 2.15 & 7.19 & 77.60 \\
7 & 1.76 & 5.87 & 83.48 \\
8 & 1.33 & 4.45 & 87.94 \\
9 & 1.27 & 4.24 & 92.19 \\
10 & 0.81 & 2.72 & 94.92 \\
11 & 0.66 & 2.22 & 97.14 \\
12 & 0.39 & 1.32 & 98.46 \\
13 & 0.32 & 1.09 & 99.56 \\
14 & 0.12 & 0.43 & 99.99 \\
15 & 0.00 & 0.00 & 99.99 \\
16 & 0.00 & 0.00 & 99.99 \\
17 & 0.00 & 0.00 & 99.99 \\
18 & 0.00 & 0.00 & 99.99 \\
19 & 0.00 & 0.00 & 99.99 \\
20 & 0.00 & 0.00 & 99.99 \\
21 & 0.00 & 0.00 & 99.99 \\
22 & 0.00 & 0.00 & 99.99 \\
23 & 0.00 & 0.00 & 99.99 \\
24 & 0.00 & 0.00 & 99.99 \\
25 & 0.00 & 0.00 & 99.99 \\
26 & 0.00 & 0.00 & 99.99 \\
27 & 0.00 & 0.00 & 99.99 \\
28 & 0.00 & 0.00 & 99.99 \\
29 & 0.00 & 0.00 & 100 \\
30 & 0.00 & 0.00 &
\end{tabular}




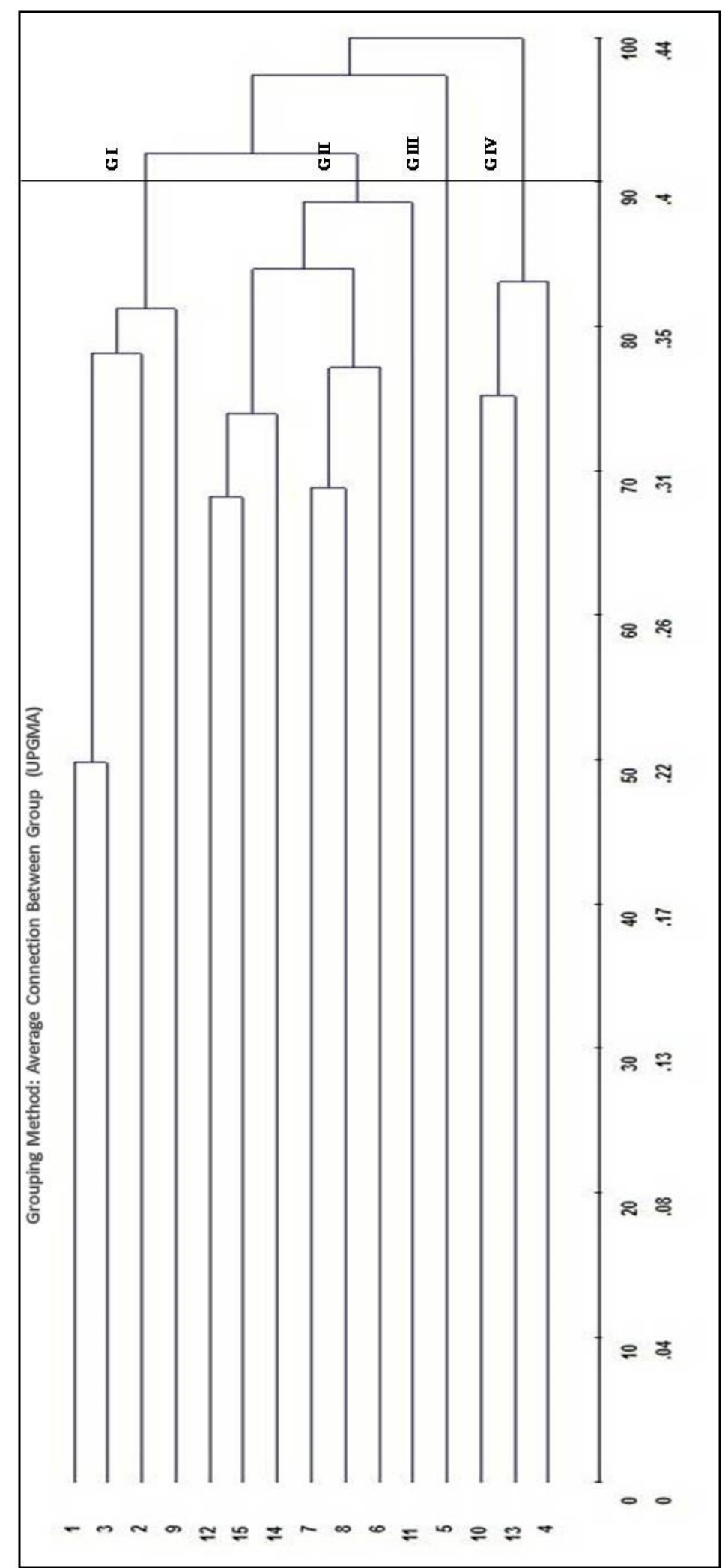

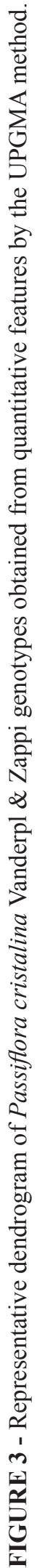




\section{CONCLUSION}

The features of greatest contribution for genetic variability of the study genotypes are fresh fruit weight, stigma length, corona filament length, fruit width, petal width and pulp weight. Therefore, they are considered the most responsive for selection of genotypes. Genotypes 4, 5 and 9 are best suited for crossing in future breeding and genetic conservation programs of the species.

\section{ACKNOWLEDGMENTS}

To the Mato Grosso State Research Foundation (FAPEMAT) and the Coordination for the Improvement of Higher Level Personnel (CAPES) and the BIONORTE Project: Conhecimento, uso Sustentável e Bioprospecção da Biodiversidade na Amazônia Meridional - Process No. 554330 / 20105 , contribution 24 .

\section{REFERENCES}

ALVES, R.M.; GARCIA, A.A.G.F; CRUZ, E.D.; FILGUEIRA, A. Seleção de descritores botânicosagronômicos para a caracterização de germoplasma de cupuçuazeiro. Pesquisa Agropecuária Brasileira, Brasília, DF, v.38, n.7, p.807-818, 2003.

ARRIEL, E.F.; PAULA, R.C.; BAKKE, O.A.; ARRIEL, N.H.C. Divergência genética em Cnidoscolus phyllacanthus (Mart.) Pax. et K. Hoffm. Revista de oleaginosas e fibrosas, Campina grande, v. 8, n. 2/3, p. 813-822, 2004.

BELLON.G.; FALEIRO, G.F.; PEIXOTO, J.R.; JUNQUEIRA, K.P.; JUNQUEIRA N.T.V.; FONSCECA, K.G.; BRAGA, M.F. Variabilidade genética de acessos obtidos de populações cultivadas e silvestres de maracujazeiro-doce com base em marcadores RAPD. São Paulo. Revista Brasileira de Fruticultura, Jaboticabal, v.31, n.1, p.197-202, 2009.

BELO, G.O. Análises morfológicas e genéticas em Progênie hibrida $F_{1}$ do cruzamento de Passiflora gardneri Mast. x Passiflora gibertii N.E.Brown. 2010. 66 f. Dissertação (Mestrado em Produção Vegetal) - Universidade Estadual de Santa Cruz, Ilhéus, 2010.
CROCHEMORE, M.L.; MOLINARI, H.B.; STENZEL, N.M.C. Caracterização agromorfológica do maracujazeiro (Passiflora spp.). Revista Brasileira de Fruticultura, Jaboticabal, v. 25, n.1, p. 5-10, 2003.

CRUZ, C. D.; Programa Genes: diversidade genética. Viçosa: UFV, 2008. 278p.

CRUZ, C. D.; REGAZZI, A. J. Modelos biométricos aplicados ao melhoramento genético. Viçosa: UFV, Imprensa Universitária, 1997. 390 p.

CRUZ, C.D., CARNEIRO, P.C.S. Modelos biométricos aplicados ao melhoramento genético. 2.ed. Viçosa: UFV, 2006. 585p.

CRUZ, C.D.; CARNEIRO, P.C.S. Modelos biométricos aplicados ao melhoramento genético. Viçosa: UFV, 2003. 585 p.

CRUZ, C.D.; REGAZZI, A.J.; CARNEIRO, P.C.S. Modelos biométricos aplicados ao melhoramento genético. Viçosa: UFV, 2004. 480p.

CUNHA, M.A.P., BARBOSA, L.V., G.A.; LIMA A.de; CUNHA, M; A.P. Maracujá: produção e qualidade na passicultura. Cruz das Almas: Embrapa Mandioca e Fruticultura, 2004. 396p.

FERREIRA, F.R. Recursos genéticos de Passiflora. In: FALEIRO, F.G.; JUNQUEIRA, N.T.V.; BRAGA, M.F.(Ed.). Maracujá: germoplasma e melhoramento genético. Planaltina, DF: Embrapa Cerrados, 2005. p. 41-51.

GODOY, R.C.B.; LEDO C.A.S.; SANTOS A.P.; MATOS, E.L.S.; LIMAA.A.; WASZCZYNSKYJ, N. Diversidade genética entre acessos de maracujazeiro amarelo avaliada pelas características físico-químicas dos frutos. Revista Ceres, São Paulo, v.54, n.316, p. 541-547, 2007.

JUNQUEIRA, N.T.V., LAGE, D.A.C., BRAGA, M.D., PEIXOTO, J.R., BORGES, T.A., ANDRADE, S.R.M. Reação a doenças e produtividade de um clone de maracujazeiro azedo propagado por estaquia e enxertia em estacas herbáceas de passiflora silvestre. Revista Brasileira Fruticultura, Jaboticabal, v. 28, n. 1, p. 97-100, 2006 .

MANICA, I. Fruticultura tropical: maracujá. São Paulo: Agronômica Ceres, 1981. 160p. 
MAPA - Ministério da Agricultura, Pecuária e Abastecimento. Instruções para execução dos ensaios de distinguibilidade, homogeneidade e estabilidade de cultivares de Passiflora. Brasília, DF, 2008.

MELETTI, L. M. M. Avanços na cultura do maracujá no Brasil. Revista Brasileira Fruticultura, Jaboticabal, São Paulo, v. 33 ,n. 1, p.83-91, 2011.
MOHAMMADI, S.A.; PRASANNA, B.M. Analysis of genetic diversity in crop plants. salient statistical tools. Crop Science, Madison, v. 43, p.1235-1248, 2003.

RAPOSO, A.; MARTINS, K.; CIAMPI, A.Y.; WADT, L.H.O.; VEASEY, E.A. Diversidade genética de populações de andiroba no Baixo Acre. Pesquisa Agropecuária Brasileira, Brasília, v.42, n.9, p.12911298, 2007. 